\title{
鳥橋孝一 学位論文審査要旨
}

$\begin{array}{ccccc}\text { 主査 } & \text { 西 } & \text { 村 } & \text { 元 } & \text { 延 } \\ \text { 副主査 } & \text { 花 } & \text { 島 } & \text { 律 } & \text { 子 } \\ \text { 同 } & \text { 黒 } & \text { 﨑 } & \text { 雅 } & \text { 道 }\end{array}$

\section{主論文}

Usefulness of the Lone Star Retractor System for harvesting the superficial temporal artery: technical note

（浅側頭動脈剥離におけるローンスターレトラクターシステムの有用性 : テクニカルノー 卜)

（著者：鳥橋孝一、小椋貴文、細谷朋央、中島定男、坂本誠、黒﨑雅道）

令和元年 British Journal of Neurosurgery 3 巻 1頁 4頁

\section{参考論文}

1. Independent predictors for recurrence of chronic subdural hematoma: a review of 343 consecutive surgical cases

（慢性硬膜下血腫の再発に関与する独立した因子：343例の連続症例の検討）

（著者：鳥橋孝一、定政信猛、吉田和道、鳴海治、沈正樹、山形専）

平成20年 Neurosurgery 63巻 1125頁～1129頁

2. The method for placement of an intraoperative continuous facial nerve stimulating electrode in acoustic neuroma surgery: technical note

（聴神経腫瘍手術における持続電極の留置方法）

(著者：鳥橋孝一、楚良繁雄、佐藤博明、河野道宏)

平成30年 Neurologia Medico Chirurgica 58巻 477頁～480頁 
3. High-flow bypass with internal carotid artery to middle cerebral artery bypass using radial artery graft through the supramandibular-subzygomatic route for giant internal carotid aneurysm: technical case report

（内頚動脈巨大脳動脈瘤に対して下顎骨上部煩骨下部のグラフトルートを作成し、 橈骨動脈を用いてハイフローバイパスを行った症例）

（著者：鳥橋孝一、門脇光俊、坂本誠、黒﨑雅道）

平成30年 World Neurosurgery 120巻 138頁～142頁 


\section{学 位 論 文 要 旨}

Usefulness of the Lone Star Retractor System for harvesting the superficial temporal artery: technical note

（浅側頭動脈剥離におけるローンスターレトラクターシステムの有用性 : テクニカルノー ト)

動脈硬化性疾患、もやもや病、複雑な動脈瘤に対する頭蓋外頭蓋内バイパス術は有効性 が示されているが、技術的にいくつかの困難なステップがある。難易度を要する手技の 1 つに浅側頭動脈 superficial temporal artery（STA）の剥離がある。STAの剥離には様々な 方法があるが、組織に適度な緊張を掛けることが重要とされている。ローンスターレトラ クターシステムは腹部外科や頭頸部外科領域において用いられる器具であり、術野を広げ ることや組織に適度な緊張を掛けることに有用である。バイパス術においてローンスター レトラクターシステムを用いることで、迅速かつ安全にSTAの剥離を行うための方法を報告 する。

\section{方 法}

ローンスターレトラクターシステムはレトラクターリング $(14.1 \mathrm{~cm} \times 14.1 \mathrm{~cm})$ とエラ スティックステイ $(5 \mathrm{~mm}$ シャープ）から構成される。レトラクターリングは自由に形状を 変えることが出来るため、どのような術野でも安定して設置することが可能である。形状 はスクリューを調整することで自由に変えることが出来る。エラスティックステイにはフ ツクと持ち手が付いており、顕微鏡操作下でも、術者や助手が簡単に素早く扱うことが可 能である。エラスティックステイはバンドの部分を構成しており、組織に掛ける緊張を適 度に調整することが出来る。レトラクターリングには20カ所の溝が付いており、全方向に 自由に掛けることが可能である。

○手術方法

執刀開始前にドップラーを用いてSTAの拍動を皮膚上にトレースする。レトラクターリン グは術野を取り囲むようにドレーピングテープを用いて固定する。STAの直上を切開し、煩 骨弓から頭頂部に向かってSTAの頭頂枝を剥離する。STAの剥離は顕微鏡下で行うが、エラ スティックステイを皮膚に掛け、組織に適度な緊張を掛けていくことで、剥離が容易とな る。エラスティックステイは両側から掛けることで、STA周囲の粗な結合織に緊張を掛け、 視認性を改善することで容易に剥離することが出来る。組織に緊張を掛けることで止血も 可能であり、剥離操作が容易となる。STAを約 $8 \mathrm{~cm}$ 剥離したところで前額部に切開を延長し、 前頭枝の剥離を行う。筋肉の翻転を行う際にもエラスティックステイを組織に掛けること 
で止血が可能である。術野を広げることも可能であり、硬膜内の血管の剥離や吻合も容易 となる。

\section{結 果}

2015 年 11 月から 2018 年 8 月まで 26 人（男性16人、女性 10 人）の患者に対してバイパス手術 を行った。25例がSTA-MCA（中大脳動脈 middle cerebral artery）バイパスであり、1例が ハイフローバイパスのアシストバイパスとしてSTA-MCAバイパスを用いた。14例がもやもや 病であり、11例が動脈硬化性疾患、1例が内頚動脈巨大脳動脈瘤であった。全ての患者で ローンスターレトラクターシステムを用いてSTAの剥離を行い、平均の手術時間は $261 \pm 78$ 分であった。全症例で術後CT、MRIでバイパスの開存を確認することが出来た。STAの剥離 に際して、血管損傷・合併症は認めなかった。

\section{考 察}

ローンスターレトラクターシステム用いることには利点があり、1つは顕微鏡操作下で あっても片手で術者や助手が操作可能であり、STA周囲の結合織を挙上、緊張を掛けること で剥離が容易となる。もう一つはSTAの剥離後にエラスティックステイを筋肉や皮膚に掛け ることで、止血操作や術野を開創することが容易となる。

STAの剥離には様々な器具が使われているが、剥離を行う場合は、皮膚やSTA周囲の結合 織を挙上し、緊張を掛けることが重要である。エラスティックステイは結合織の視認性を 改善し、剥離を容易とする。レトラクターリングには4つのスクリューがあり、自由に形状 を調整し、どの方向にも緊張を掛けることが可能であり、術野にあった形で適合させるこ とが可能である。

ローンスターレトラクターシステムの大きな利点の1つとして、筋肉にエラスティックス テイを掛けることで止血が容易に可能である。バイパス術の吻合操作において、硬膜内に 出血を認めない術野環境は重要である。エラスティックステイには持ち手が付いており、 器具を使って持ち替える必要もなく、顕微鏡下に術者や助手が扱えることが可能であり、 操作は容易である。

\section{結 論}

頭蓋外頭蓋内バイパス術においてローンスターレトラクターシステムを用いたSTAの剥 離方法について述べた。ローンスターレトラクターシステムは顕微鏡下に術者や助手が片 手で容易に操作することが可能である。STA周囲の結合織に緊張を掛けることで剥離を容 易にし、皮膚や筋肉に掛けることで、止血や術野の展開に役立つと考えられる。 